\title{
Translationally-Controlled Tumor Protein
}

National Cancer Institute

\section{Source}

National Cancer Institute. Translationally-Controlled Tumor Protein. NCI Thesaurus. Code C101391.

Translationally-controlled tumor protein (172 aa, $20 \mathrm{kDa}$ ) is encoded by the human TPT1 gene. This protein is involved in both calcium binding and microtubule polymerization. 